\title{
Faktor yang Mempengaruhi Kriteria Lokasi Berdagang Pedagang Kaki Lima Berdasarkan Preferensi Pedagang Kaki Lima di Kawasan Pasar Baru Gresik
}

\author{
Fitri Dwi Agus Maulidiyah dan Hertiari Idajati \\ Perencanaan Wilayah dan Kota, Fakultas Teknik Sipil dan Perencanaan \\ Institut Teknologi Sepuluh Nopember (ITS) \\ Jl. Arief Rahman Hakim, Surabaya 60111 Indonesia \\ e-mail: hertiari.idajati@urplan.its.ac.id
}

\begin{abstract}
Abstrak-Permasalahan utama PKL di Kawasan Pasar Baru Gresik adalah banyaknya kegagalan relokasi yang disebabkan kurangnya keterlibatan PKL dalam menentukan lokasi berdagang PKL. Oleh karena itu, penelitian ini bertujuan untuk menentukan faktor yang mempengaruhi kriteria lokasi pedagang kaki lima berdasarkan preferensi pedagang kaki lima itu sendiri di Kawasan Pasar Baru Gresik. Tahapan penelitian yang dilakukan adalah mengidentifikasi karakteristik pedagang kaki lima dengan menggunakan teknik analisa statistik desktiptif. Kemudian menentukan faktor yang mempengaruhi kriteria lokasi berdagang berdasarkan preferensi pedagang kaki lima dengan menggunakan content analysis. Maka dari itu hasil dari penelitian adalah faktor yang mempengaruhi kriteria lokasi berdagang pedagang kaki lima di Kawasan Pasar Baru Gresik yaitu sebagai berikut: (1) Lokasi berdagang yang strategis; (2) Harga sewa lahan/kios; (3) Dekat dengan kegiatan masyarakat; (4) Visibilitas; (5) Retribusi; (6) Dekat dengan permukiman penduduk; (7) Ketersediaan lahan parkir; (8) Dekat dengan terminal/stasiun; (9) Ketersediaan tempat pembuangan sampah; (10) Dekat dengan tempat tinggal; (11) Ketersediaan transportasi umum (12) Ketersdiaan jaringan air bersih; (13) Memiliki akses keluar dan masuk; (14) Penerimaan produk yang ditawarkan; (15) Ketersediaan drainase; (16) Ketersediaan pelayanan listrik; (17) Pengelompokkan jenis barang dagangan; (18) Luas tempat berdagang.
\end{abstract}

Kata Kunci-sektor Informal, PKL, kriteria penentuan lokasi

\section{PENDAHULUAN}

$S$ UATU aktivitas penting di perkotaan adalah aktivitas perdagangan. Salah satunya yaitu berada pada sektor informal, dimana sektor memiliki daya serap tenaga kerja yang cukup besar dan berperan sebagai penyangga yang sangat lentur dan terbuka, bahkan menjadi ujung tombak pemasaran yang potensial [1].

Pedagang kaki lima (PKL) adalah bentuk perdagangan sektor informal yang keberadaannya tidak bisa dihindari khususnya dinegara-negara berkembang. Keberadaan PKL sendiri dapat memberikan keuntungan kepadaa semua pihak yang bersangkutan jika PKL tersebut dapat dikendalikan dengan baik [1]. PKL memiliki dampak postif dan juga negatif, dimana dampak positif dari adanya PKL yaitu dapat menjadi alternatif untuk mengurangi jumlah pengangguran dan dampak negatif dari keberadaan PKL yaitu PKL menempati ruang-ruang publik yang bukan untuk peruntukkannya [3].

Kawasan perkotaan Gresik mengalami permasalahan yang tidak terlepas dari keberadaan PKL. Dimana perkotaan Gresik merupakan bagian dari Surabaya Metropolitan Area (SMA) dengan salah satu fungsi sebagai kawasan perdagangan dan jasa [4]. PKL di perkotaan Gresik semakin banyak dan tidak terkendali sehingga menimbulkan permasalahan bagi lingkungan sekitarnya, jumlah PKL yang terdapat di Kabupaten Gresik mencapai 1510 PKL [5]. Adapun PKL yang terdapat pada Pasar Baru Gresik sebagai kawasan penelitian pada tahun 2013 sebanyak 187 PKL. [6]

Sebagai upaya pengendalian, Pemerintah Kabupaten Gresik melakukan relokasi dan penertiban PKL di kawasan penelitian ke Pasar Krempyeng yang lokasinya tidak jauh dari kawasan penelitian. Namun PKL tetap saja kembali ke tempat yang telah ditertibkan dengan lapak seadanya dan membayar sewa kepada tukang parkir yang perharinya mencapai Rp 20.000,00 dengan alasan lebih banyak pengunjung [7]. Hal tersebut dikarenakan lokasi berdagang yang disediakan oleh pemerintah berada pada bagian belakang Pasar Krempyeng sehingga keberadaan PKL tidak terlihat pengunjung dan mengakibatkan pendapatan PKL menurun.

Oleh karena itu, perlu adanya perlu adanya keterlibatan PKL dalam menentukan faktor yang mempengaruhi kriteria lokasi berdagang PKL sehingga diharapkan pemerintah sebagai regulator dapat mempertimbangkan keinginan PKL dalam menentukan lokasi berdagang PKL. Tujuan dari penelitian ini adalah untuk mengetahui faktor yang mempengaruhi kriteria lokasi berdagang pedagang kaki lima berdasarkan preferensi pedagang kaki lima agar upaya pengendalian PKL di kawasan perkotaan Gresik optimal dan dapat menjadi rekomendasi dalam kebijakan penataan dan pengendalian PKL. Adapun sasaran yang dicapai adalah mengidentifikasi karakteristik PKL dan menentukan faktor yang berpengaruh berdasaarkan preferensi PKL. 


\section{METODE PENELITIAN}

\section{A. Jenis dan Pendekatan Penelitian}

Pendekatan yang digunakan dalam penelitian ini adalah pendekatan rasionalistik. [8] Jenis penelitian dalam penelitian ini adalah deskripti kuantitatif. [1]

\section{B. Variabel Penelitian}

Variabel penelitian yang digunakan untuk menentukan faktor yang mempengaruhi yaitu lokasi yang strategis, memiliki akses keluar dan masuk, ketersediaan transportasi umum, sewa lahan/kios dengan harga murah, retribusi, ketersediaan tempat pembuangan sampah, ketersediaan jaringan drainase, ketersediaan lahan parkir, ketersediaan jaringan listrik, ketersediaan jaringan air bersih, dekat dengan terminal/stasiun, dekat dengan tempat tinggal, dekat dengan permukiman penduduk, dekat dengan kegiatan masyarakat, daerah sekitar menerima produk yang ditawarkan, dan visibilitas.

C. Menganalisa Faktor-Faktor yang Mepengaruhi Kriteria Lokasi Berdagang Pedagang Kaki Lima Berdasarkan Preferensi Pedagang Kaki Lima

Dalam menganalisis faktor yang mempengaruhi kriteria lokasi berdagang PKL di Kawasan Pasar Baru Gresik, penulis menggunakan alat analisa content analysis. Tahapan content analysis yang dilakukan dalam penelitian ini meliputi:

1) Menyusun kuisioner yang akan digunakan untuk memwawancarai narasumber

2) Melakukan wawancara yang sifatnya mendalam (in-depht interview)

3) Mentranskrip hasil wawancara yang telah didapat

4) Memberikan kode pada catatan transkrip wawancara

5) Mengklarifikasi data

6) Melakukan prediksi data

\section{HASIL DAN DISKUSI}

\section{A. Gambaran Umum}

Penelitian ini berlokasi di Kawasan Pasar Baru Gresik. Lokasi ini merupakan kawsan perdagangan dan jasa di perkotaan Gresik.

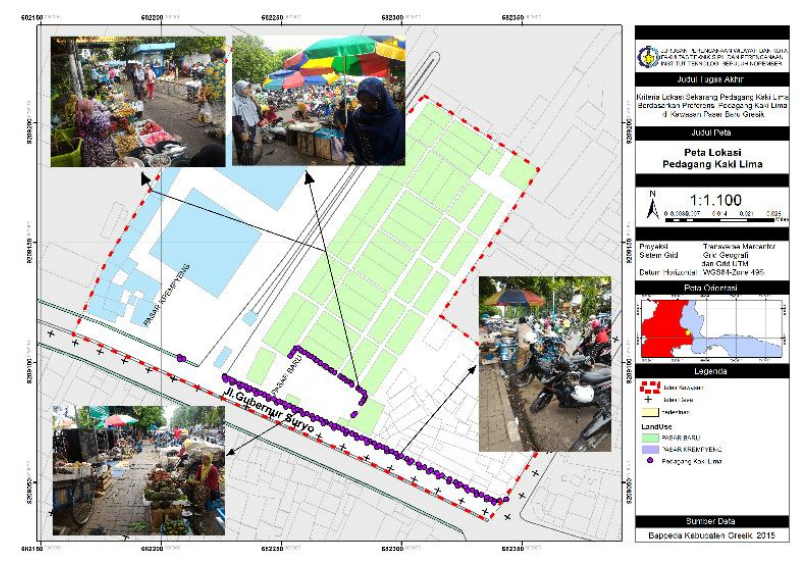

Gambar 1. Peta lokasi berdagang pedagang kaki lima di Kawasan Pasar Baru Gresik
B. Menentukan Faktor-Faktor yang Mempengaruhi Kriteria Lokasi Pedagang Kaki Lima Berdasarkan Preferensi Pedagang Kaki Lima di Kawasan Pasar Baru Gresik

Dalam menentukan faktor yang mempengaruhi kriteria lokasi PKL berdasarkan preferensi pedagang kaki lima meliputi aspek aksesibilitas, aspek ekonomi, aspek sarana dan prasarana dan aspek lingkungan dengan menggunakan teknik analisis content analysis. Tahap pertama, peneliti mencari $\mathrm{Q}$ responden dengan menggunakan teknik sampling snowballing. Teknik sampling tersebut digunakan karena peneliti tidak mengetahui narasumber untuk dijadikan informan. Kemudian membuat daftar pertanyaan, kemudian melakukan wawancara dengan narasumber yang telah didapat dari teknik sampling snowballing. Setelah menggunakan teknik sampling snowballing didapatkan 4 responden sebagai narasumber, yaitu Responden 1: Ketua paguyuban PKL; Responden 2: Pedagang yang berlokasi di trotoar; Responden 3: Pedagang yang berlokasi di badan jalan; Responden 4: Pedagang yang berlokasi di lahan parkir.

Analisis ini dilakukan berdasarkan hasil koding yang terdapat pada transkrip wawancara dan telah disesuaikan dengan variabel penelitian. Setelah proses analisis dilakukan maka didapatkan 16 faktor yang berpengaruh dengan tambahan 2 faktor baru dan 1 faktor yang tidak berpengaruh. Berikut adalah tabel hasil dari conten analysisi. 
Tabel 1

Hasil Content Analysis

Faktor-Faktor yang Mempengaruhi Kriteria Lokasi Berdagang PKL Berdasarkan Preferensi PKL di Kawasan Pasar Baru Gresik

\begin{tabular}{|c|c|c|c|c|c|c|c|c|c|}
\hline \multirow[b]{2}{*}{ No. } & \multirow[b]{2}{*}{$\begin{array}{c}\text { Variabel Kriteria } \\
\text { Lokasi }\end{array}$} & \multicolumn{2}{|c|}{ Responden 1} & \multicolumn{2}{|c|}{ Responden 2} & \multicolumn{2}{|c|}{ Responden 3} & \multicolumn{2}{|c|}{ Responden 4} \\
\hline & & $\begin{array}{l}\text { Berpe } \\
\text { ngaruh }\end{array}$ & $\begin{array}{c}\text { Tidak } \\
\text { Berpe } \\
\text { ngaruh }\end{array}$ & $\begin{array}{l}\text { Berpe } \\
\text { ngaruh }\end{array}$ & $\begin{array}{c}\text { Tidak } \\
\text { Berpe } \\
\text { ngaruh }\end{array}$ & $\begin{array}{l}\text { Berpe } \\
\text { ngaruh }\end{array}$ & $\begin{array}{c}\text { Tidak } \\
\text { Berpe } \\
\text { ngaruh }\end{array}$ & $\begin{array}{l}\text { Berpe } \\
\text { ngaruh }\end{array}$ & $\begin{array}{c}\text { Tidak Berpe } \\
\text { ngaruh }\end{array}$ \\
\hline 1. & $\begin{array}{l}\text { Lokasi Berdagang Yang } \\
\text { Strategis }\end{array}$ & 2 & - & 2 & 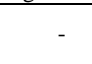 & 2 & - & 10 & - \\
\hline 2. & $\begin{array}{l}\text { Akses Keluar dan Masuk } \\
\text { Lokasi Berdagang }\end{array}$ & - & - & - & - & - & - & 2 & - \\
\hline 3. & $\begin{array}{l}\text { Ketersediaan Transportasi } \\
\text { Umum }\end{array}$ & 1 & - & 1 & - & - & - & 1 & - \\
\hline 4. & Harga Sewa Lahan / Kios & 2 & - & 1 & - & 2 & - & 4 & - \\
\hline 5. & Retribusi & - & - & 2 & - & 3 & - & 4 & - \\
\hline 6. & Ketersediaan Drainase & 2 & - & - & - & - & - & - & - \\
\hline 7. & $\begin{array}{l}\text { Ketersediaan Pelayanan } \\
\text { Listrik }\end{array}$ & 1 & - & - & - & - & 1 & 1 & - \\
\hline 8. & $\begin{array}{l}\text { Ketersediaan Jaringan Air } \\
\text { Bersih }\end{array}$ & 1 & - & - & - & 1 & - & - & - \\
\hline 9. & $\begin{array}{l}\text { Ketersediaan Tempat } \\
\text { Pembuangan Sampah }\end{array}$ & 1 & - & 1 & - & 1 & - & 1 & - \\
\hline 10. & Ketersediaan Lahan Parkir & 2 & - & 2 & - & - & - & 2 & - \\
\hline 11. & Visibilitas & 4 & - & 1 & - & 4 & - & - & - \\
\hline 12. & Dekat Dengan Permukiman & 2 & - & 1 & - & 1 & - & 2 & - \\
\hline 13. & $\begin{array}{l}\text { Dekat Dengan Terminal / } \\
\text { Stasiun }\end{array}$ & - & - & 2 & - & 1 & - & - & - \\
\hline 14. & Dekat Dengan Tempat Tinggal & - & - & 1 & - & 1 & - & 1 & - \\
\hline 15. & $\begin{array}{l}\text { Dekat Dengan Kegiatan } \\
\text { Masyarakat }\end{array}$ & 1 & - & 5 & - & 2 & - & 1 & - \\
\hline 16. & $\begin{array}{l}\text { Daerah Sekitar Mendukung } \\
\text { Produk Yang Ditawarkan }\end{array}$ & 1 & - & - & - & 1 & - & - & - \\
\hline \multicolumn{10}{|c|}{ Variabel Baru } \\
\hline 17. & $\begin{array}{l}\text { Pengelompok- } \\
\text { an jenis barang dagangan }\end{array}$ & 3 & - & 2 & - & - & - & - & - \\
\hline \multicolumn{9}{|c|}{ Variabel Tidak Berpengaruh } & - \\
\hline 19. & Persaingan antar pedagang & - & 1 & - & 2 & 1 & - & - & 2 \\
\hline
\end{tabular}

Sumber: Hasil analisa, 2016

Keterangan:

R1: Ketua paguyuban PKL

R2: Pedagang di lokasi trotoar

R3: Pedagang di lokasi badan jalan

R4: Pedagang di lokasi lahan parkir

Berdasarkan dari tabel diatas yang menunjuk 4 responden sebagai narasumber dari keseluruhan variabel penelitian yaitu didapatkan faktor yang mempengaruhi kriteria lokasi berdagang PKL yang didasarkan ppada preferensi PKL di Kawasan Pasar Baru Gresik. Dimana faktor-faktor yang berpengaruh dalam menentukan kriteria lokasi berdagang PKL berdasarkan preferensi PKL sesuai dengan tingkat pengaruhnya adalah:

\section{1) Lokasi berdagang yang strategis}

Dengan pengulangan kata sebanyak 16 kali dapat diketahui lokasi berdagang yang strategis berpengaruh dalam kriteria lokasi PKL yang didasarkan pada preferensi PKL di kawasan penelitian, dengan alasan bahwa lokasi berdagang yang strategis termasuk tempat yang layak untuk merelokasi PKL. Dengan tempat yang strategis PKL pasti tidak akan kembali ke lokasi berdagang yang telah ditertibkan.

"Karena PKL menginginkan tempat yang layak dan strategis, setidaknya terdapat tempat yang peruntukkannya dikhususkan untuk $P K L "$

(Ahmad Yani, PKL berlokasi di lahan parkir, 2016).

2) Visibilitas

Dengan pengulangan kata sebanyak 9 kali dapat diketahui lokasi berdagang terlihat dari jalan raya (visibilitas) berpengaruh dalam kriteria lokasi PKL yang didasarkan pada preferensi PKL di kawasan penelitian, dengan alasan bahwa PKL pasti akan berjualan yang dekat dengan jalan raya. Dengan demikian meskipun PKL tersebut tetap berdagang dengan lokasi yang dekat dengan jalan raya tetapi tidak melanggar peraturan yang ada

"PKL akan selalu menempati lokasi yang mudah terlihat dari pinggir jalan raya oleh calon pembeli nya"

(Edi, Ketua Paguyuban PKL, 2016).

3) Retribusi

Dengan pengulangan kata sebanyak 9 kali dapat diketahui bahwa variabel retribusi berpengaruh dalam kriteria lokasi PKL yang didasarkan pada preferensi PKL di kawasan penelitian, dengan alasan bahwa penarikan retribusi akan sangat berpengaruh dengan lokasi berdagang PKL. Dengan hal tersebut maka lokasi PKL akan lebih terlihat tertib, rapi dan bersih. Bahkan PKL akan sangat senang dan tidak keberatan jika harus membayar retribusi karena dengan begitu berarti mereka merasa dihargai dan merasa dianggap ada.

"PKL bersedia membayar retribusi selama retribusi tersebut sesuai dengan kemampuan PKL, karenadengan seperti itu keberadaaan PKL merasa akan dianggap keberadaannya." (Ahmad Yani, PKL berlokasi di lahan parkir, 2016)

4) Harga sewa lahan/kios

Dengan pengulangan kata sebanyak 9 kali dapat diketahui bahwa variabel harga sewa kios berpengaruh dalam kriteria lokasi PKL yang didasarkan pada preferensi PKL di kawasan penelitian, dengan alasan bahwa harga sewa kios yang sesuai dengan kemampuan PKL akan sangat menunjang PKL dan tidak membebankan PKL. Dengan 
harga sewa kios yang tidak terlalu mahal dan dapat dijangkau PKL, maka PKL akan mau direlokasi dan tidak akan kembali ke lokasi berdagang yang telah ditertibkan.

"Karena sewa lahan/kios yang terlalu mahal akan membebankan PKL"

(Ahmad Yani, PKL berlokasi di lahan parkir, 2016).

5) Dekat dengan kegiatan masyarakat

Dengan pengulangan kata sebanyak 9 kali dapat diketahui bahwa variabel dekat dengan kegiatan masyarakat berpengaruh dalam kriteria lokasi PKL yang didasarkan pada preferensi PKL di kawasan penelitian, dengan alasan bahwa lokasi berdagang yang dekat dengan kegiatan masyarakat sangat diminati oleh PKL, hal tersebut akan menarik perhatian pengunjung untuk melihat barang dagangan yang ditawarkan oleh PKL tersebut.

"Karena kedekatan lokasi berdagang dengan kegiatan masyarakat dapat menarik minat pengunjung sekitar “

(Mariati, PKL berlokasi di badan jalan, 2016)

6) Ketersediaan lahan parkir

Dengan pengulangan kata sebanyak 6 kali dapat diketahui bahwa variabel ketersediaan lahan parkir berpengaruh dalam kriteria lokasi PKL yang didasarkan pada preferensi PKL di kawasan penelitian, dengan alasan bahwa ketersediaan lahan parkir pada lokasi berdagang yang baru akan mempermudah pengunjung yang membawa kendaraan pribadi. Dengan demikian lokasi sekitar tempat berdagang akan terlihat lebih rapi dan tidak ada kendaraan yang parkir dengan seenaknya sendiri.

"Ketersediaan lahan parkir sangat dibutuhkan untuk pengunjung agar pengunjung merasa aman dan nyaman untuk memarkirkan kendaraannya"

(Edi, Ketua Paguyuban PKL, 2016).

7) Dekat dengan permukiman

Dengan pengulangan kata sebanyak 6 kali dapat diketahui bahwa variabel dekat dengan permukiman penduduk berpengaruh dalam kriteria lokasi PKL yang didasarkan pada preferensi PKL di kawasan penelitian, dengan alasan bahwa lokasi yang berdagang yang baru akan lebih menguntung PKL jika lokasi tersebut dekat dengan permukiman penduduk.

"Karena jika lingkungan sekitar lokasi berdagang yang baru dekat dengan permukiman akan mempermudah masyarakat sekitar untuk berbelanja “

(Edi, Ketua paguyuban PKL, 2016).

8) Ketersediaan tempat pembuangan sampah

Dengan pengulangan kata sebanyak 4 kali dapat diketahui bahwa variabel ketersediaan tempat pembuangan sampah berpengaruh dalam kriteria lokasi PKL yang didasarkan pada preferensi PKL di kawasan penelitian, dengan alasan bahwa lokasi berdagang yang ketersediaan tempat sampahnya mencukupi lokasi berdagang PKL akan tetap bersih. Dengan adanya kebersihan tersebut pembeli dan pedagang akan sama-sama enak. Jadi tidak ada sampah yang berserakan dan tempatnya menjadi bersih.

"Ketersediaan tempat pembuangan sampah sangat diperlukan agar lokasi berdagang terlihat rapi dan bersih" (Edi, Ketua paguyuban PKL, 2016).
9) Ketersediaan transportasi umum

Dengan pengulangan kata sebanyak 3 kali dapat diketauhi bahwa variabel ketersediaan transportasi umum berpengaruh dalam kriteria lokasi PKL yang didasarkan pada preferensi PKL di kawasan penelitian, dengan alasan bahwa lokasi berdagang yang mudah untuk dijangkau transportasi umum akan memudahkan pengunjung dan pedagang untuk menuju ke lokasi tersebut.

"Karena tersedianya transportasi umum yang rutenya melewati lokasi berdagang akan sangat menunjang pedagang"

(Edi, Ketua paguyuban PKL, 2016).

10) Dekat dengan stasiun/terminal

Dengan pengulangan kata sebanyak 3 kali dapat diketahui bahwa variabel dekat dengan terminal/stasiun berpengaruh dalam kriteria lokasi PKL yang didasarkan pada preferensi PKL di kawasan penelitian, dengan alasan bahwa lokasi berdagang yang dekat dengan terminal/stasiun akan menguntungkan PKL yaitu akan banyak pengunjung dari dalam Kota Gresik atau bahkan pengunjung dari luar Kota Gresik yang mungkin tertarik untuk mengunjungi lokasi berdagang PKL. Hal tersebut juga akan menguntungkan pengunjung yang akan berkunjung ataupun telah berkunjung ke lokasi berdagang PKL tersebut agar tidak susah mendapatkan angkutan umum yang sesuai dengan tujuannya.

"Karena kedekatan lokasi berdagang dengan terminal/stasiun akan mendatangkan banyak pengunjung dari dalam maupun luar kota Gresik. Hal tersebut juga akan mempermudah pengunjung dan pedagang untuk mendapatkan angkuta umum"

( Mariati, PKL berlokasi di trotoar 2016) .

11) Dekat dengan tempat tinggal

Dengan pengulangan kata sebanyak 3 kali dapat diketahui bahwa

"Karena kedekatan lokasi berdagang dengan tempat tinggal akan menghemat biaya transportasi."

( Mariati, PKL berlokasi di trotoar 2016) .

\section{2) Ketersediaan drainase}

Dengan pengulangan kata sebanyak 2 kali. variabel ketersediaan drainase berpengaruh dalam kriteria lokasi PKL yang didasarkan pada preferensi PKL di kawasan penelitian, dengan alasan bahwa dengan adanya jaringan drainase maka pedagang yang memiliki limbah cari tidak akan membuang limbah dagangannya kesembarang tempat agar tidak menyebabkan genangan dan lokasi berdagang yang becek.

"Karena ketersediaan drainase sangat dibuthkan. Agar tidak terjadi banjur dan genangan di lokasi berdagang"

(Edi, Ketua paguyuban PKL, 2016).

13) Ketersediaan jaringan air bersih

Dengan pengulangan kata sebanyak 2 kali dapat diketahui bahwa ketersediaan pelayanan air bersih tidak berpengaruh dalam kriteria lokasi PKL yang didasarkan pada preferensi PKL di kawasan penelitian, dengan alasan bahwa air bersih merupakan kebutuhan pokok dan kebutuhan sehari-hari.

"Ketersediaan air bersih sangat dibutuhkan, karena pada 
kondisi eksisting berlum tersedianya ketersediaan air bersih "

(Edi, Ketua paguyuban PKL, 2016).

14) Daerah sekitar menerima produk yang ditawarkan

Dengan pengulangan kata sebanyak 2 kali dapat diketahui bahwa variabel penerimaan produk yang ditawarkan berpengaruh dalam kriteria lokasi PKL yang didasarkan pada preferensi PKL di kawasan penelitian, dengan alasan bahwa barang yang ditawarkan/diperdagangkan merupakan kebutuhan sehari-hari dari masyarakat. Namum barang dengan kualitas yang bagus dan kejujuran pedagang akan membuat pengunjung merasa dihargai dan hal tersebut juga mengungutngkan pedagang.

"Karena barang yang diperdagangkan adalah barangbarang kebutuhan sehari-hari. Maka dari itu produk yang ditawarkan akan diterima oleh masyarakat di lingkungan sekitar lokasi berdagang yang baru “

(Edi, Ketua paguyuban PKL, 2016).

15) Memiliki akses keluar dan masuk

Dengan pengulangan kata sebanyak 2 kali dapat diketahui bahwa variabel akses keluar dan masuk berpengaruh dalam kriteria lokasi PKL yang didasarkan pada preferensi PKL di kawasan penelitian, dengan alasan kelacaran akses keluar dan masuk lokasi berdagang sangat menunjang peedagang itu sendiri, dengan adanya kelancaran tersebut maka kenyamanan pengunjung pun terjamin. Hal tersebut menjadikan pedagang dan pengunjung sama-sama diuntungkan.

"Karena pengunjung membutuhkan akses yang baik dan nyaman"

(Ahmad Yani, PKL berlokasi di lahan parkir, 2016).

16) Ketersediaan pelayanan listrik

yaitu dengan pengulangan kata sebanyak 2 kali dapat diketahui bahwa variabel ketersediaan jaringan listrik berpengaruh dalam kriteria lokasi PKL yang didasarkan pada preferensi PKL di kawasan penelitian, dengan alasan bahwa ketersediaan jaringan listrik akan dibutuhkan oleh PKL yang berjualan hingga malam hari dan PKL yang berjualannya dimulai pada malam hari.

"Karena terdapat PKL yang berjualan baru sore hingga malam hari dan terdapat PKL yang berjualan pada waktu malam hari hingga pagi/siang hari. Maka ketersediaan pelayanan listrik dibutuhkan"

(Ahmad Yani, PKL berlokasi di lahan parkir, 2016).

Kemudian dari hasil analisa content analysis didapatkan dua variabel baru yaitu:

1) Pengelompokkan jenis barang dagangan

Dengan pengulangan kata sebanyak 5 kali dapat diketahui bahwa variabel baru yang didapatkan yaitu pengelompokkan jenis barang dagangan dalam kriteria lokasi PKL berdasarkan preferensi pedagang kaki lima di kawasan penelitian bahwa pengelompokkan jenis barang dagangan yang sama akan memudahkan pengunjung dan tenpat berdagang akan terlihat lebih rapi.

"Karena hal tersebut akan mempermudah pengunjung dalam menemukan barang yang dicari ataupun yang akan dibeli. Selain itu hal tersebut akan menjadikan lokasi berdagang semakin rapi dan bersih “

(Edi, Ketua paguyuban PKL, 2016).

2) Luas tempat berdagang

Dengan pengulangan kata sebanyak 1 kali variabel baru yang didapatkan yaitu luas tempat berdagang dalam kriteria lokasi PKL berdasarkan preferensi pedagang kaki lima di kawasan penelitian bahwa dengan disamaratakan luasan untuk berdagang maka tempat berjualan akan terlihat lebih rapi dan tertib.

"Karena paling tidak disamaratakann setiap pedagang memiliki luas tempat berdagang $2 m^{2}$ agar terlihat rapu dan tertata"

(Siti, PKL berlokasi di badan jalan, 2016).

Namun dari hasil analisa tersebut terdapat satu variabel yang tidak berpengaruh yaitu persaingan antar pedagang dengan 5 kali pengulangan kata, dapat diketahui bahwa variabel persaingan antar pedagang tidak berpengaruh dalam kriteria lokasi PKL yang didasarkan pada preferensi PKL di kawasan penelitian, dengan alasan bahwa lokasi berdagang yang berkelompok sesuai dengan jenis barang dagangannya akan terlihat lebih rapi dan lebih banyak menarik perhatian pengunjung. Dengan demikian persaingan harga jual antar pedagang pasti akan terjadi, namum PKL tidak akan mempermasalahkan hal tersebut karena persaingan antar pedagang merupakan hal yang wajar dan biasa terjadi.

"Karena persaingan disetiap pedagang pasti ada dan hal tersebut adalah hal yang wajar. Namun persaingan tersebut tidak akan berbeda terlalu tinggi dari segi harga"

(Edi, Ketua paguyuban PKL, 2016).

Faktor-faktor berpengaruh yang telah diperoleh diatas terdapat beberapa variabel yang dapat dikelompokkan yaitu lokasi berdagang yang strategis meliputi: visibilitas; dekat dengan kegiatan masyarakat; dekat dengan pemukiman penduduk; dekat dengan terminal/stasiun; dekat degan tempat tinggal; ketersediaan transportasi umum. Sarana dan prasarana penunjang yang meliputi: ketersediaan lahan parkir; ketersediaan tempat pembuangan sampah; ketersediaan jaringan air bersih; ketersediaan drainase; ketersediaan pelayanan listrik, harga sewa lahan/kios; retribusi; memiliki akses keluar dan masuk; peneriman produk yang ditawarkan; luas tempat berdagang.

\section{KESIMPULAN}

Dari hasil pembahasan diatas, dapat ditarik kesimpulan dari penelitian yang dilakukan, yaitu agar tidak terjadi kegagalan dalam merelokasi PKL. Maka perlu mengetahui faktor-faktor yang berpengaruh dalam menentukan kriteria lokasi berdagang PKL di Kawasan Pasar Baru Gresik. Dimana faktor-faktor yang berpengaruh dalam menentukan kritetria lokasi berdagang PKL di Kawasan Pasar Baru Gresik adalah:

1) Lokasi berdagang yang strategis yang meliputi : visibilitas, dekat dengan kegiatan masyarakat, dekat dengan pemukiman penduduk, dekat dengan terminal/stasiun, dekat degan tempat tinggal, ketersediaan transportasi umum.

2) Memiiki sarana dan prasarana yang menunjang, seperti ketersediaan lahan parkir, ketersediaan tempat 
pembuangan sampah, ketersediaan jaringan air bersih, ketersediaan drainase, ketersediaan pelayanan listrik.

3) Harga sewa lahan/kios

4) Retribusi

5) Memiliki akses keluar dan masuk

6) Penerimaan produk yang ditawarkan

7) Pengelompokkan jenis barang dagangan

8) Luas tempat berdagang

\section{DAFTAR PUSTAKA}

[1] Rolis, Ilyas. 2013. Sektor Informal Perkotaan dan Ikhtiar Pemberdayaannya. Jurnal Sosiologi Islam Volume 3 N0 02 Oktober 2013. Surabaya: IAIN Sunan Ampel Surabaya.

[2] Ginting, Salmina. 2004. Studi Kasus: Pengaruh Keberadaan Pedagang Kaki Lima Terhadap Jumlah Pengunjung Taman Kota di Medan. Jurnal teknik SIMENTRIKA Vol 3 No.3. Sumatera Utara: Universitas Supatera Utara

[3] Rahayuni, Adi. 2012. Pola Penyebaran Pedagang Kaki Lima (PKL) di Kota Singaraja. Jurnal Pendidikan Geografi. Singaraja: Undiksha

[4] RTRW Kabupaten Gresik Tahun 2010-2030

[5] Ainul, Roziana. 2012. Klasifikasi dan Spesialisasi Pedagang Kaki Lima di Kabupaten Gresik. Jurnal From JIPPTUMG. Gresik: Universitas Muhammadiyah Gresik

[6] Sa'diyah, Siti. 2013. Konflik Antara Pedagang Stand Dengan Pedagang Kaki Lima di Pasar Baru Gresik.Tugas Akhir. Program Sarjana Studi Sosiologi. Surabaya: Institut Agama Islam Sunan Ampel.

[7] Surya

Online. http://surabaya.tribunnews.com/2013/09/26/empat-hariditertibkan-pkl-kembali-jualan-di-area-pakir. 2015

[8] Imam Asy'ari, Sapari. 1993. Sosiologi Kota dan Desa. Surabaya : Usaha Nasional Surabaya 